\title{
GOSPODAROWANIE KAPITAŁEM LUDZKIM Z UWZGLĘDNIENIEM PERSPEKTYWY PŁCI
}

\section{WSTĘP}

Przedmiotem niniejszego artykułu jest zagadnienie gospodarowania kapitałem ludzkim z uwzględnieniem perspektywy płci zarówno w skali mikro-, jak i makroekonomicznej. Zakres czasowy został określony na lata 1993-2013, natomiast terytorialny obejmuje obszar Polski. Artykuł ma na celu próbę odpowiedzi na cztery kluczowe pytania w kontekście problematyki gospodarowania kapitałem ludzkim z uwzględnieniem perspektywy płci: Jak być powinno? Jak jest w rzeczywistości? Dlaczego tak jest? Jak eliminować problemy i dążyć do poprawy?

Aby osiągnąć postawione zadanie badawcze, kolejno zostaną przedstawione następujące kwestie. Punktem wyjścia rozważań będzie analiza regulacji prawnych wprowadzanych na rzecz równości płci. Przedstawione zostaną rozwiązania funkcjonujące w polskim prawodawstwie w kontekście uregulowań unijnych oraz międzynarodowych. Kolejnym istotnym aspektem będzie analiza statystyczno-ekonomiczna sytuacji na polskim rynku pracy z uwzględnieniem perspektywy płci. Zostaną również zaprezentowane wyniki badania Gender Inequality Index, które jest miernikiem strat w kapitale ludzkim spowodowanych dysproporcjami w kształtowaniu się sytuacji kobiet i mężczyzn. Następnie zostanie podjęta próba teoretycznego uzasadnienia zaistniałej sytuacji na podstawie współczesnych teorii dyskryminacji ekonomicznej kobiet. Zostaną przeanalizowane również działania oraz projekty, które podejmują problematykę wyrównywania szans kobiet i mężczyzn oraz wdrażania zarządzania różnorodnością w organizacji. W ramach podsumowania zostaną omówione najważniejsze wnioski oraz rekomendacje.

* Doktorantka, Katedra Makroekonomii i Badań nad Rozwojem, Wydział Ekonomii, Uniwersytet Ekonomiczny w Poznaniu. 


\section{KAPITAŁ LUDZKI - PODSTAWOWE POJĘCIA}

We współczesnej myśli ekonomicznej kapitał ludzki traktowany jest dwojako. W ujęciu szerokim ${ }^{1}$ definiowany jest jako nagromadzone w człowieku i w społeczeństwie jako całości umiejętności, zdolności, wiedza, energia witalna oraz zdrowie. To z kolei implikuje zdolność do pracy, do adaptacji zmian w otoczeniu i możliwości kreacji nowych rozwiązań. Ujęcie wąskie ${ }^{2}$ koncentruje się wokół kapitału ludzkiego w działalności gospodarczej. Mamy tu na myśli ogół predyspozycji, wiedzy, zdolności i umiejętności pracowników, które stanowią o ich kompetencjach. W tym ujęciu, kapitał ludzki ma wewnętrzną moc wytwarzania wartości. Warto również dodać, iż kapitał ludzki może być ciągle udoskonalany poprzez inwestowanie - w toku uczenia się i nabywania umiejętności, ale może również ulegać deprecjacjỉ . Łącząc przedstawione perspektywy, kapitał ludzki ${ }^{4}$ można uznać za zdobytą przez zasoby pracy, w czasie kształcenia, wiedzę i umiejętności. Ponadto w definiowaniu kapitału ludzkiego należy uwzględnić czynniki zarówno wewnętrzne, tj. psychofizyczne, jak i zewnętrzne, np. instytucjonalne, które wpływają na wykonywanie pracy zawodowej.

Biorąc pod uwagę zarówno perspektywę mikro- i makroekonomiczną, jak i ujęcie szerokie oraz wąskie - kapitał ludzki jest immanentną częścią rzeczywistości gospodarczej. Jego ścisły związek z funkcjonowaniem przedsiębiorstw oraz całych gospodarek narodowych polega na budowaniu ich przewag konkurencyjnych opartych na wiedzy. W związku z tym tak istotne jest umiejętne gospodarowanie kapitałem ludzkim, czyli wykorzystywanie jego potencjalnych mocy wytwórczych - przy uwzględnieniu zróżnicowania jakim się charakteryzuje - tak aby osiągać jak największe korzyści.

\section{UWARUNKOWANIA PRAWNE ZARZĄDZANIA KAPITAŁEM LUDZKIM}

Rozważania należy rozpocząć od przedstawienia sytuacji przewidzianej w prawie w kontekście równości płci. Analiza regulacji prawnych pozwoli odpowiedzieć na pytanie, jak być powinno. Zaprezentuje stan prawny w Polsce na tle uregulowań międzynarodowych. Polska jako członek Organizacji Narodów Zjednoczonych (ONZ), Międzynarodowej Organizacji Pracy (MOP) czy Unii Europejskiej (UE) ma obowiązek realizacji konwencji oraz deklaracji dotyczących równości płci, które są przez te organizacje ustanawiane. Wiele regulacji prawnych ma charakter interdyscyplinarny, łączący problem dyskryminacji na rynku pracy z innymi dziedzinami, odnoszący się

\footnotetext{
1 E. Kryńska, E. Kwiatkowski, Podstawy wiedzy o rynku pracy, Łódź 2013, s. 145-146.

2 Ibidem, s. 146-147.

3 G. Wronowska, Kapitał ludzki - ujęcie teoretyczne, Kraków 2012, s. 21-22.

4 S. Roszkowska, Kapitał ludzki a wzrost gospodarczy w Polsce, Łódź 2013, s. 16.
} 
na przykład do praw człowieka, czego przykładem jest Powszechna Deklaracja Praw Człowieka ${ }^{5}$. Regulacje o zasięgu międzynarodowym koncentrują się przede wszystkim wokół działalności ONZ, której główne osiągnięcia prezentuje tabela 1.

Tabela 1. Regulacje prawne ONZ dotyczące równości płci

\begin{tabular}{cll}
\hline Rok wdrożenia & \multicolumn{1}{c}{ Nazwa aktu prawnego } & \multicolumn{1}{c}{ Główne założenia } \\
\hline \multirow{2}{*}{1979} & $\begin{array}{l}\text { Konwencja w sprawie likwidacji } \\
\text { wszelkich form dyskryminacji } \\
\text { kobiet }- \text { Międzynarodowa Karta } \\
\text { Praw Kobiet }\end{array}$ & $\begin{array}{l}\text { Wprowadziła zakaz różnicowania, wyklu- } \\
\text { czania ze względu na płeć oraz postulowała } \\
\text { zniwelowanie dyskryminacji kobiet w sferze } \\
\text { oświaty, zatrudnienia, działalności gospo- } \\
\text { darczej oraz w życiu społecznym. }\end{array}$ \\
\hline \multirow{2}{*}{1993} & Deklaracja Wiedeńska & $\begin{array}{l}\text { Podkreśliła znaczenie działań na rzecz współ- } \\
\text { uczestnictwa kobiet w życiu gospodarczym, } \\
\text { politycznym i społecznym. }\end{array}$ \\
\hline \multirow{2}{*}{2000} & Pekińska Platforma Działania & $\begin{array}{l}\text { Określiła cele strategiczne na rzecz zwiększa- } \\
\text { nia roli kobiet w gospodarce, polityce oraz } \\
\text { wdrożyła gender mainstreaming. }\end{array}$ \\
\hline
\end{tabular}

ŹRóDŁo: J. Hurek, M. Maj, Równość płci a innowacyjność - stan obecny i rekomendacje na przyszłość, Warszawa 2012, s. 18; T. Kowalak, Kobieta we współczesnym świecie, Białystok 2006, s. 28-31.

Podpisane przez polską dyplomację konwencje MOP nr 100 i 111 wdrażają obowiązek zakazu dyskryminacji ekonomicznej kobiet w zakresie zatrudniania, awansowania oraz wynagradzania ${ }^{6}$. Najważniejsze traktaty unijne - rzymski oraz amsterdamski - wprowadzają zasadę niedyskryminacji jako ogólną regułę prawa unijnego. W Konstytucji RP z 1997 roku zawarto zasadę równego statusu płci oraz zasadę równego dostępu kobiet i mężczyzn do edukacji, zatrudnienia, awansów i pełnienia funkcji publicznych, równego wynagrodzenia oraz zabezpieczenia społecznego ${ }^{7}$. Kodeks pracy zawiera szereg regulacji dotyczących m.in. równego traktowania kobiet i mężczyzn przez pracodawców, równego dostępu do awansów, jednakowych wynagrodzeń za tę samą pracę czy zakazu stosowania wszelkich form dyskryminacji.

Wszelkie obowiązujące w Polsce regulacje prawne dążą do wdrożenia idei gender mainstreaming $\mathrm{w}$ realizacji procesów politycznych, gospodarczych i społecznych $^{8}$. Chodzi przede wszystkim o rzeczywiste wyrównanie sytuacji życiowej kobiet

5 B. Kalinowska-Nawrotek, Dyskryminacja kobiet na polskim rynku pracy, Poznań 2005, s. 19.

6 T. Kowalak, Kobieta..., s. 30-31.

7 J. Hurek, M. Maj, Równość..., s. 23.

8 I. Andruszkiewicz, Równouprawnienie kobiet i mężczyzn na rynku pracy, [w:] C. Sadowska-Snarska (red.), Równowaga. Praca - życie - rodzina, Białystok 2008, s. 212-220. 
i mężczyzn, tak aby mieli oni równe prawa i obowiązki, równe szanse rozwoju oraz równy dostęp do zasobów. Traktat amsterdamski uregulował te praktyki, natomiast Strategia lizbońska uznała gender mainstreaming za niezbędne narzędzie do osiągnięcia planowanego rozwoju poziomu spójności ekonomicznej oraz społecznej.

Polityka równości płci jest realizowana poprzez programy oraz projekty obejmujące obszary: rynku pracy, edukacji, zdrowia, władzy. Unaoczniają one bariery w skutecznym zarządzaniu kapitałem ludzkim ${ }^{9}$ w tym m.in.: poziomą i pionową segregację rynku pracy, różnice w płacach kobiet i mężczyzn, małą dostępność elastycznych form czasu pracy, niski udział mężczyzn w wypełnianiu obowiązków rodzinnych, niski udział kobiet w procesach podejmowania decyzji, przemoc ze względu na płeć, niewidoczność kwestii płci w ochronie zdrowia, stereotypy płci.

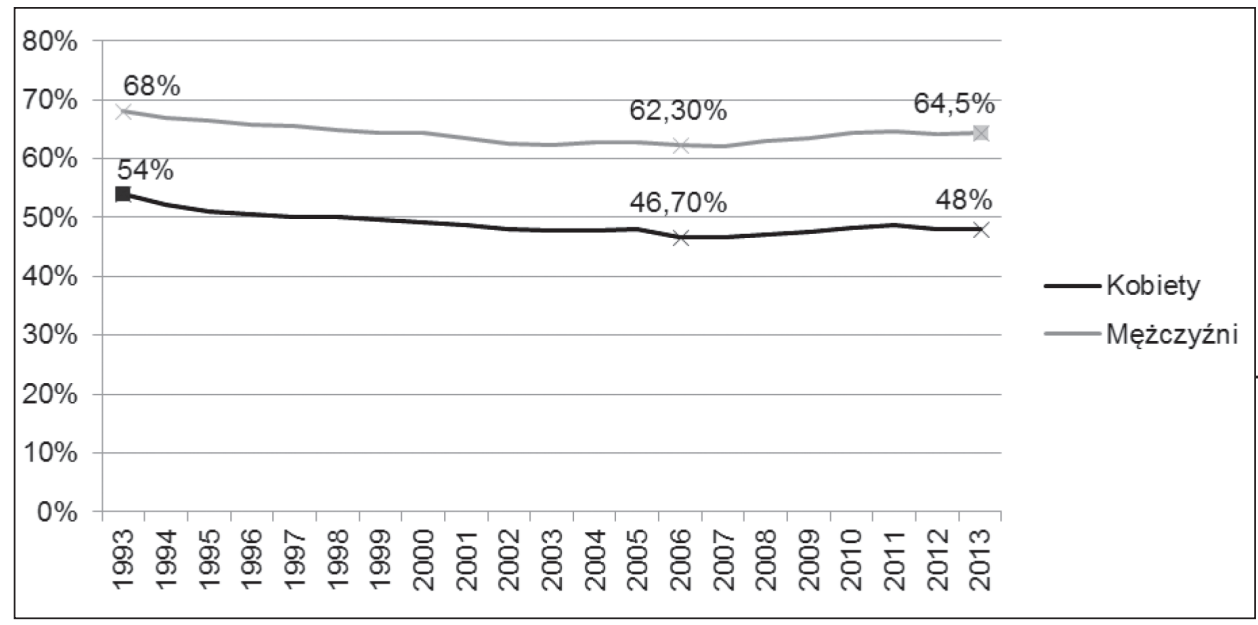

Wykres 1. Współczynnik aktywności zawodowej kobiet i mężczyzn w Polsce w latach 1993-2013 (stan w IV kwartale, według BAEL) ${ }^{10}$

ŹRódŁo: S. Golinowska (red.), W trosce o pracę. Raport o rozwoju społecznym, Warszawa 2004,

s. 171; GUS, Kobiety i mężczyźni na rynku pracy, Warszawa 2004, s. 2; idem, Kobiety i mężczyźni na polskim rynku pracy 2012, Warszawa 2012, s. 2; idem, Monitoring rynku pracy. Kwartalna informacja o aktywności ekonomicznej ludności - IV kwartał 2013, Zakład Wydawnictw Statystycznych, Warszawa 2013, www.stat.gov.pl/cps/rde/xbcr/gus/PW_kwartalna_inf_o_ rynku_pracy_4kw_2013.pdf [dostęp: 22.0.2015]

9 M. Branka, M. Rawłuszko, A. Siekiera, Zasada równości szans kobiet i mężczyzn w projektach Programu Operacyjnego Kapitał Ludzki, Warszawa 2009, www.efs.gov.pl/Wiadomosci/Documents/zasadarownociszans.pdf [dostęp: 22.01.2015].

10 S. Golinowska (red.), W trosce o pracę. Raport o rozwoju społecznym, Warszawa 2004, s. 171; GUS, Kobiety i mężczyźni na rynku pracy, Warszawa 2004, s. 2; idem, Kobiety i mężczyźni na polskim rynku pracy, Warszawa 2012, s. 2; idem, Monitoring rynku pracy. Kwartalna informacja o aktywności ekonomicznej ludności - IV kwartał 2013, Zakład Wydawnictw Statystycznych, Warszawa 2013, www.stat.gov.pl/cps/rde/xbcr/gus/PW_kwartalna_inf_o_rynku_pracy_4kw_2013. pdf [dostęp: 22.01.2015]. 
Wykres 1 przedstawia wartości współczynnika aktywności zawodowej ${ }^{11}$ (jest to procentowy udział ludności aktywnej zawodowo, czyli pracujących i bezrobotnych, w ogólnej liczbie ludności w wieku 15 lat i więcej) kobiet i mężczyzn w Polsce w latach 1993-2013. Wynika z niego, iż poziom aktywności zawodowej wśród kobiet był niższy niż wśród mężczyzn. Była to tendencja stała, kształtująca się na średnim poziomie 15 p.p. różnicy między płciami w latach 1993-2013. Poziom aktywności zawodowej mierzony współczynnikiem aktywności zawodowej wśród mężczyzn wahał się od 60 do 70\%, natomiast wśród kobiet - między 40 a 60\%. Wskazuje to na większe rozbieżności oraz fluktuacje w przypadku kobiet. Warto również zwrócić uwagę na zasób osób biernych zawodowo w Polsce. W tej grupie dominowały kobiety, które częściej niż mężczyźni posiadały status osoby biernej zawodowo.

Aby wyodrębnić oraz scharakteryzować grupę osób pracujących, należy przyjrzeć się wykresowi 2, na którym zaprezentowano wskaźnik zatrudnienia12 (jest to procentowy udział osób pracujących w ogólnej liczbie ludności w wieku 15 lat i więcej) kobiet i mężczyzn w Polsce w latach 1993-2013.

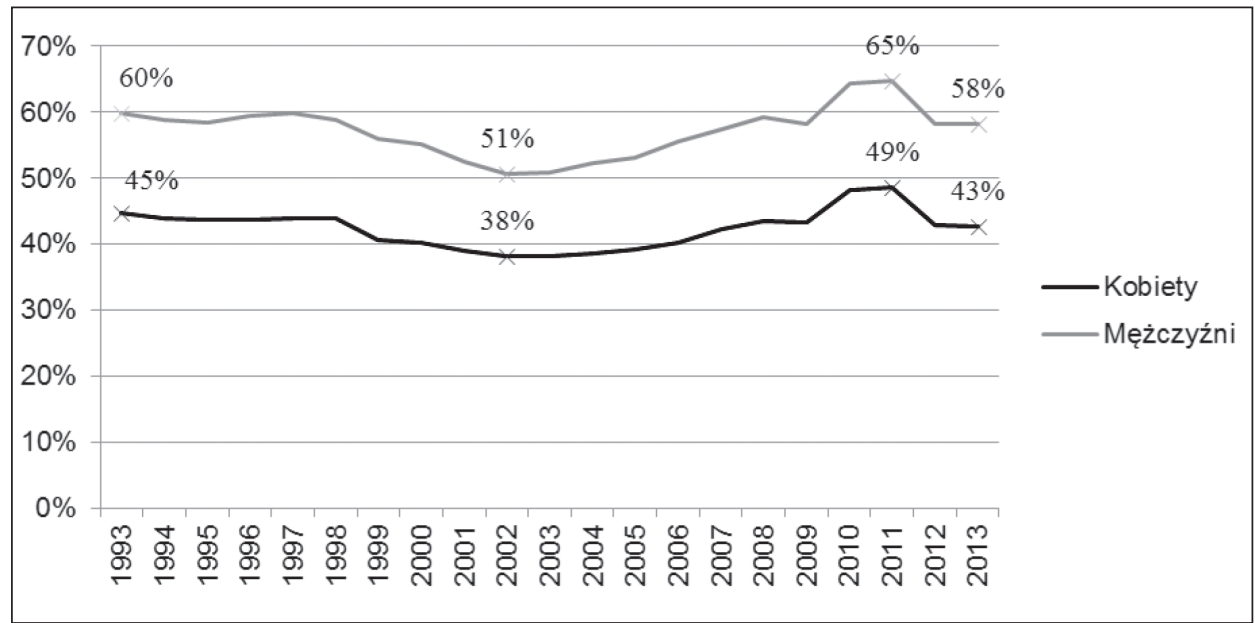

Wykres 2. Wskaźnik zatrudnienia kobiet i mężczyzn w Polsce w latach 1993-2013 (stan w IV kwartale, według BAEL)

ŹRódŁo: E. Czerwińska, Rynek pracy w Polsce, Warszawa 1995, s. 2; GUS, Kobiety..., s. 4; idem, Monitoring..., s. 4-6

Analiza statystyczno-ekonomiczna przeprowadzona w oparciu o wykres 2 wskazuje na to, że różnica pomiędzy wskaźnikiem zatrudnienia dla kobiet i dla mężczyzn kształtowała się na średnim poziomie 15 p.p. w latach 1993-2013. Kolejną płaszczyzną

11 GUS, Monitoring..., s. 11.

12 Ibidem, s. 11. 
analizy nierówności płci może być zjawisko bezrobocia. Wykres 3 prezentuje kształtowanie się stopy bezrobocia ${ }^{13}$ (jest to procentowy udział osób bezrobotnych w ogólnej liczbie ludności aktywnej zawodowo w wieku 15 lat i więcej) wśród kobiet i mężczyzn w Polsce w latach 1993-2013.

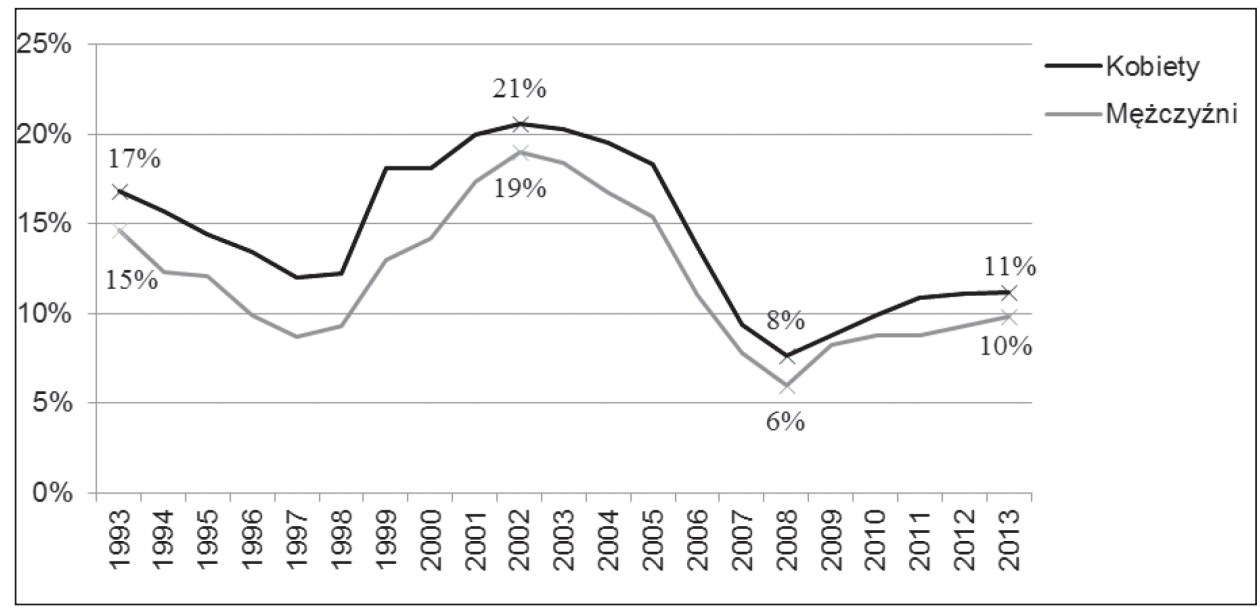

Wykres 3. Stopa bezrobocia kobiet i mężczyzn w Polsce w latach 1993-2013 (stan w IV kwartale, według BAEL)

ŹRóDŁo: E. Czerwińska, Rynek..., s. 22; S. Golinowska, W trosce o pracę..., s. 173; GUS, Kobiety..., s. 7; idem, Monitoring..., s. 7-9

Stopa bezrobocia wśród kobiet w Polsce w latach 1993-2013 kształtowała się na wyższym poziomie niż stopa bezrobocia wśród mężczyzn. Rozbieżności kształtujące się przeciętnie na poziomie 3-4 p.p. stopniowo malały, jednak w związku ze skutkami kryzysu finansowo-gospodarczego zaczęły się pogłębiać. Może to więc oznaczać większą wrażliwość pozycji kobiet na rynku pracy w obliczu szoków gospodarczych, a co za tym idzie większe od mężczyzn zagrożenie bezrobociem.

Problematyka nierówności płci w zakresie zatrudnienia powinna zostać rozpatrzona nie tylko z perspektywy ilościowej, ale również jakościowej. Posłużyć ma temu analiza zjawisk poziomej i pionowej segregacji zawodowej kobiet.

W ujęciu poziomym ${ }^{14}$ segregacja zawodowa polega na podziale zatrudnionych według sekcji gospodarki narodowej. Problemem towarzyszącym poziomej segregacji zawodowej jest zjawisko „lepkiej podłogi”15, które umiejscawia kobiety w zawodach

13 Ibidem.

14 W. Jarmołowicz, B. Kalinowska, Praca i płaca kobiet na polskim i unijnym rynku pracy, [w:] W. Jarmołowicz (red.), Przemiany na współczesnym rynku pracy, Poznań 2008, s. 149-171.

15 E. Mandal, Kobiety i mężczyźni a praca zawodowa, [w:] E. Mandal (red.), W kręgu gender, Katowice 2007, s. 79-89. 
sekcji gorzej płatnych, o mniejszych możliwościach awansu oraz niskim statusie i prestiżu. W 2013 roku do najbardziej sfeminizowanych sekcji gospodarki należały „opieka zdrowotna i pomoc społeczna” (82\% kobiet) oraz „edukacja” (78,5\% kobiet) ${ }^{16}$. Kobiety stanowiły przeciętnie ok. 75\% zatrudnionych w danych sekcjach w latach 1993-2013. Zmaskulinizowane sekcje gospodarki to przede wszystkim: "budownictwo" (kobiety w 2013 roku stanowiły tu poniżej 10\% wszystkich zatrudnionych) oraz „górnictwo i wydobywanie” (poniżej 15\% wszystkich pracujących).

W ujęciu pionowym segregacja zawodowa oznacza podział pracujących według grup zawodowych. Charakteryzuje ją występowanie zjawiska „szklanego sufitu”17. Symbolizuje on istnienie niewidzialnej bariery w awansie zawodowym na kolejny szczebel w hierarchii organizacji. Zjawiskiem pokrewnym jest problem „szklanych ścian”18, który wiąże się z trudnością w awansowaniu ze stanowiska pomocniczego na kierownicze oraz zjawisko „szklanych ruchomych schodów”. To ostatnie oznacza, iż nawet w zawodach sfeminizowanych na stanowiska kierownicze łatwiej awansują mężczyźni.

Reasumując, kobiety zdecydowanie rzadziej niż mężczyźni zajmują stanowiska wyższego szczebla oraz zasiadają w gremiach decyzyjnych. W całej gospodarce, w 2013 roku, 37\% kobiet znalazło się grupie zawodowej „przedstawiciele władz publicznych, wyżsi urzędnicy, kierownicy"19. W obecnie trwającej kadencji mamy 24\% kobiet w Sejmie RP i 12\% kobiet w Senacie RP. Według danych Komisji Europejskiej20 - 10,3\% kobiet zasiadało w 2013 roku w zarządach spółek giełdowych w Polsce, na tle 16,8\% (przeciętny odsetek kobiet w zarządach spółek giełdowych dla UE-27). Ciekawym zagadnieniem z punktu widzenia omawianej problematyki jest odsetek kobiet pracujących na własny rachunek oraz będących pracodawczyniami. W 2011 roku było to $12 \%$ pracujących kobiet oraz 22,5\% pracujących mężczyzn²1. Zdecydowanie mniej kobiet niż mężczyzn zajmowało się własną działalnością gospodarczą. Podsumowując, można stwierdzić, że zjawiska poziomej i pionowej segregacji zawodowej były obecne w omawianym okresie w realiach polskiego rynku pracy.

\section{GENDER INEQUALITY INDEX - NARZĘDZIE DO ANALIZY KAPITAŁU LUDZKIEGO}

Dążąc do ukazania złożonego obszaru gospodarowania kapitałem ludzkim z uwzględnieniem płci, należy zwrócić szczególną uwagę na Gender Inequality Index (GII), czyli indeks nierówności płci. Jest on publikowany od 2010 roku przez ONZ

16 GUS, Kobiety i mężczyźni na rynku pracy 2013, Warszawa 2014, s. 9.

17 W. Jarmołowicz, B. Kalinowska, Praca..., s. 159.

18 M. Musiał-Karg, Kobiety na rynku pracy - wybrane zagadnienia, [w:] K. Knochenmuss (red.), Mentoring dla kobiet. Szeroka droga do kariery, Słubice 2010, s. 15-19.

19 GUS, Kobiety..., s. 9-10.

20 Komisja Europejska, Jak zwiększyć liczbę kobiet na najwyższych stanowiskach?, www. ec.europa.eu/news/justice/120305_pl.htm [dostęp: 23.01.2015].

21 GUS, Kobiety..., s. 4. 
w ramach działania Programu Narodów Zjednoczonych ds. Rozwoju22. Gll stanowi syntezę założeń i celów wszystkich aktów prawnych ONZ dotyczących równości płci oraz narzędzie do monitorowania ich wdrażania. Koncentrując się na omawianym wskaźniku, należy zauważyć, iż mierzy on straty w rozwoju kapitału ludzkiego spowodowane dysproporcjami pomiędzy kobietami a mężczyznami. G/l przyjmuje wartości od 0 (sytuacja taka oznacza, że kobiety i mężczyźni radzą sobie równie dobrze w badanych obszarach) do 1 (stan wskazujący na zdecydowanie bardziej niekorzystną pozycję kobiet w stosunku do mężczyzn w branych pod uwagę wymiarach rozwoju). GIl ma na celu ujawnić, w jakim stopniu krajowe osiągnięcia w badanych aspektach rozwoju człowieka ulegają deprecjacji przez nierówności płci. G/l powinien być interpretowany jako procentowy ubytek wywołany nierównościami płci w stosunku do potencjalnego rozwoju człowieka w omawianych obszarach. Dodatkowo chodzi o zapewnienie empirycznych podstaw do analizy prowadzonej polityki krajowej oraz inicjatyw wspierających równość płci. G/l ma być przydatny w zrozumieniu konsekwencji wywoływanych dysproporcjami między kobietami a mężczyznami w ramach ochrony zdrowia, dostępu do edukacji oraz władzy, a także w kontekście ich obecności na rynku pracy. Tabela 2 przedstawia poszczególne obszary i wskaźniki wykorzystywane do konstrukcji GIl.

Tabela 2. Gender Inequality Index - badane obszary i wykorzystywane wskaźniki

\begin{tabular}{|c|c|c|}
\hline Sfera zdrowia reprodukcyjnego & Sfera edukacji i władzy & Sfera rynku pracy \\
\hline $\begin{array}{l}\text { Umieralność kobiet przy poro- } \\
\text { dzie: stosunek liczby zgonów } \\
\text { kobiet przy porodzie do liczby } \\
\text { żywych urodzeń (liczony na } \\
100000 \text { żywych urodzeń) }\end{array}$ & $\begin{array}{l}\text { Uczestnictwo kobiet i mężczyzn } \\
\text { w edukacji na szczeblu śred- } \\
\text { nim i wyższym: odsetek kobiet } \\
\text { i mężczyzn powyżej } 25 \text { roku ży- } \\
\text { cia posiadających przynajmniej } \\
\text { wykształcenie średnie }\end{array}$ & \multirow{2}{*}{$\begin{array}{l}\text { Uczestnictwo kobiet i męż- } \\
\text { czyzn w rynku pracy: wskaź- } \\
\text { niki aktywności zawodowej } \\
\text { kobiet i mężczyzn }\end{array}$} \\
\hline $\begin{array}{l}\text { Płodność nieletnich: liczba uro- } \\
\text { dzeń przypadająca na } 1000 \\
\text { kobiet w wieku 15-19 lat }\end{array}$ & $\begin{array}{l}\text { Udział kobiet i mężczyzn w par- } \\
\text { lamencie: procentowy udział } \\
\text { kobiet zajmujących miejsca } \\
\text { w parlamencie }\end{array}$ & \\
\hline
\end{tabular}

ŹRódŁo: K. Malik (red.), Human Development Report 2013. The Rise of the South: Human Progress in a Diverse World, Nowy Jork 2012, s. 159.

Sytuację Polski na przestrzeni lat, w których publikowano dane dotyczące GII, przedstawia tabela 3.

22 UNDP, Gender Inequality Index: Indices and Data, Nowy Jork 2013, www:hdr.undp.org/en/ statistics/gii [dostęp: 22.01.2015]. 
Tabela 3. Wskaźnik GIl w Polsce w latach: 2008, 2011, 2012, 2013

\begin{tabular}{ccc}
\hline Rok & Wartość GII & Miejsce w rankingu GII \\
\hline 2008 & $0,325=32,5 \%$ & 26 \\
\hline 2011 & $0,164=16,4 \%$ & 24 \\
\hline 2012 & $0,140=14,0 \%$ & 25 \\
\hline 2013 & $0,139=13,9 \%$ & 26 \\
\hline
\end{tabular}

ŹRóDŁo: J. Klugman (red.), Human Development Report 2011. Sustainability and Equity: A Better Future for All, Nowy Jork 2011, s. 139; K. Malik (ed.), Human..., s. 156.

Warto zauważyć, iż coraz mniejszy ubytek w rozwoju kapitału ludzkiego w Polsce jest wywoływany nierównościami płci. Różnica między rokiem 2008 a 2013 wyniosła 18,6 p.p., co oznacza zdecydowaną poprawę sytuacji w zakresie badanego problemu.

\section{WSPÓłCZESNE TEORIE NIERÓWNOŚCI PŁCI A GOSPODAROWANIE KAPITAŁEM LUDZKIM}

W związku z przedstawioną analizą statystyczno-ekonomiczną należy zastanowić się nad przyczynami sytuacji na polskim rynku pracy, która charakteryzuje się znacznymi nierównościami ze względu na płeć. Może to świadczyć o nieumiejętnym wykorzystaniu potencjału zasobów kapitału ludzkiego w polskiej gospodarce. Kolejna część artykułu ma na celu, w oparciu o współczesne teorie nierówności płci, zrewidować te uwarunkowania i odpowiedzieć na pytanie, dlaczego tak jest.

Zróżnicowanie w kapitale ludzkim jednostek oraz w szerszym ujęciu - całych gospodarek można pośrednio tłumaczyć zjawiskiem dyskryminacji typu human ca-

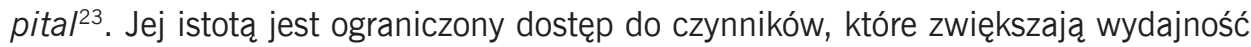
pracy. Jest to przede wszystkim selektywność w zakresie nauki, szkoleń czy praktyk zawodowych. Pokrewną koncepcji dyskryminacji typu human capital jest teoria kapitału ludzkiego. Wskazuje ona, iż to płeć jest kryterium różnicującym pracowników bez względu na ich umiejętności, zdolności, kwalifikacje oraz doświadczenie zawodowe. Zakłada się, iż kobiety charakteryzują się niższą produktywnością, co m.in. implikuje różnice w poziomie wynagrodzeń. Bardzo istotna z punktu widzenia omawianej tematyki jest dyskryminacja kwalifikacyjna i zawodowa ${ }^{24}$, która polega na tym, iż istnieją ograniczenia w dostępie do pewnych zawodów oraz stanowisk. Hipoteza stłoczenia

23 B. Kalinowska-Nawrotek, Dyskryminacja..., s. 11.

24 Ibidem, s. 11. 
w nielicznych zawodach, czyli crowding hypothesis ${ }^{25}$, zwraca uwagę na fakt, iż kobiety koncentrują się w nielicznych zawodach, co sztucznie zawyża podaż ich pracy w tych konkretnych dziedzinach. Nadreprezentacja kobiet jest szczególnie zauważalna w branżach słabszych ekonomicznie, gdzie zarówno poziom płac, jak i szanse awansu są dość niskie. Z kolei teoria kosztu informacji K. Arrowa ${ }^{26}$ traktuje pewne cechy niezwiązane z produktywnością (np. płeć) jako cenne, ponieważ są tanim rozwiązaniem w pozyskaniu informacji o pracowniku. Jeśli uznać płeć za taką cechę, to naznaczenie kobiet mniejszą produktywnością wpływa na selekcję dokonywaną przez pracodawców. Prowadzi to do kolejnej istotnej teorii - dyskryminacji statystycznej27, która przypisuje kobietom jako grupie pewien zestaw cech warunkujących ich selekcję na rynku pracy. Społeczne przyzwolenie tego typu praktyk implikuje niższe oczekiwania kobiet, co do warunków pracy i płacy. Poza tym przypisywanie wszystkim kobietom niektórych cech, np. nieciągłości zatrudnienia związanej z macierzyństwem, jest krzywdzące wobec tych, które tych cech nie posiadają. Pokrewną koncepcją jest teoria peryferyjności D. Morsa ${ }^{28}$. Wskazuje ona na istnienie grupy pracowników peryferyjnych, charakteryzujących się nieciągłością pracy lub pracą dorywczą, w niepełnym wymiarze czasu. Dotyka to często kobiet, które łączą obowiązki zawodowe z domowymi, dlatego stanowią grupę pracowników peryferyjnych. Co za tym idzie, kobiety są gorzej wynagradzane, traktowane jako pracownicy o niskim statusie w hierarchii firmy, z małymi szansami na awans zawodowy. Te zjawiska z kolei świadczą o występowaniu stygmatyzacji na rynku pracy. Ograniczenia dotyczące aktywności zawodowej kobiet pośrednio wynikają z teorii ekonomicznych tłumaczących ich dyskryminację na rynku pracy. W kontekście gospodarowania kapitałem ludzkim istotne są determinanty o podłożu społecznym i kulturowym, np. stereotypy dotyczące płci, które przyczyniają się do utrwalania pewnych niekorzystnych schematów w świadomości, postawach i zachowaniu jednostek.

\section{ANALIZA DOBRYCH PRAKTYK W KONTEKŚCIE ELIMINOWANIA NIERÓWNOŚCI PŁCI W GOSPODAROWANIU KAPITAŁEM LUDZKIM}

Po zapoznaniu się z teoretycznym uzasadnieniem trudności w gospodarowaniu kapitałem ludzkim ze względu na płeć, należy przyjrzeć się praktykom, które wychodzą naprzeciw tym ograniczeniom i barierom. Prezentowane projekty są wdrażane w Polsce, ale bazują na doświadczeniach międzynarodowych.

25 I. Reszke, Nierówności płci w teoriach. Teoretyczne wyjaśnienie płci w sferze zawodowej, Warszawa 1991, s. 82-84.

26 Ibidem, s. 86-87.

27 Ibidem, s. 91-107.

28 Ibidem, s. 114-121. 
Projekt Gender Index ${ }^{29}$ miał na celu analizę miejsc pracy pod kątem nierówności płci w takich aspektach jak: rekrutacja, awanse, ochrona przed zwolnieniami, dostęp do szkoleń, wynagrodzenia, work-life balance. Badał obszary, gdzie kapitał ludzki traci najwięcej i wdrażał praktyki naprawcze, w kontekście jego sprawniejszego gospodarowania. Projekt opierał się na formule konkursu „Firma Równych Szans", w którym na podstawie wielowymiarowej analizy określano sytuację danej firmy w kontekście przestrzegania zasad równego traktowania kobiet i mężczyzn w miejscu pracy.

Karta Różnorodności ${ }^{30}$ jest jednym z narzędzi wdrażanych w celu zwrócenia uwagi na problemy w zarządzaniu zróżnicowanym kapitałem ludzkim. Opiera się on na dążeniu do eliminacji wszelkich form dyskryminacji w miejscu pracy oraz stworzeniu środowiska sprzyjającemu promocji różnorodności. Firmy, organizacje, instytucje oraz jednostki administracji publicznej pisemnie zobowiązują się do działania na rzecz spójności i równości społecznej. Inicjatywa jest o tyle interesująca, iż angażuje sektor prywatny w zwalczanie nierówności, w tym nierówności płci oraz stwarza w środowisku biznesu atmosferę sprzyjającą zarządzaniu różnorodnością.

Projekt Diversity Index ${ }^{31}$ odpowiada na pytania, czy działania podejmowane przez firmy koncentrują się na lepszym wykorzystaniu grup defaworyzowanych na rynku pracy oraz czy różnorodność kapitału ludzkiego jest uwzględniana w strategii działania firmy, w kulturze organizacyjnej, w strukturach zatrudnienia, w elementach związanych z rekrutacją oraz rozwojem zawodowym. Dodatkowo projekt ten ma za zadanie diagnozować i monitorować politykę prowadzoną przez danego pracodawcę w kontekście zarządzania różnorodnością. W szerszym rozumieniu projekt podejmuje problem promocji idei zarządzania różnorodnym kapitałem ludzkim w Polsce.

\section{PODSUMOWANIE}

Przedstawione aspekty gospodarowania kapitałem ludzkim z uwzględnieniem perspektywy płci miały na celu weryfikację regulacji prawnych gwarantujących równość płci w kontekście analizy statystyczno-ekonomicznej polskiego rynku pracy. Rozbieżności pomiędzy polityką deklaratywną a realizowaną ujęto w teoretyczny układ wyjaśnień. Uwarunkowania problemów w gospodarowaniu kapitałem ludzkim wynikających z nierówności płci wytłumaczono m.in. współczesnymi teoriami

29 E. Lisowska, Gender Index. Monitorowanie równości kobiet i mężczyzn w miejscu pracy, Warszawa 2007, s. 6-9.

30 M. Andrejczuk, Karta różnorodności. Korzyści z zarządzania różnorodnością. Karta różnorodności w Polsce, Warszawa 2012, s. 7-14.

31 E. Lisowska, A. Sznajder, Zarządzanie różnorodnością w miejscu pracy. Raport z I Edycji Barometru Różnorodności, Warszawa 2013, s. 6-7. 
dyskryminacji ekonomicznej kobiet. Zwrócono również uwagę na projekty i działania na rzecz eliminowania problemów w zarządzaniu różnorodnym kapitałem ludzkim. Reasumując, niniejsze opracowanie wskazuje na kilka istotnych argumentów, które potwierdzają zasadność podjętej problematyki. Po pierwsze, jak wykazano, płeć jest immanentnym elementem kapitału ludzkiego, tak więc trudno jest rozpatrywać te dwa pojęcia rozłącznie. Po drugie, umiejętne zarządzanie kapitałem ludzkim wymaga zrozumienia i szacunku dla różnorodności. To z kolei jest narzędziem do osiągania równowagi niezbędnej do wielopłaszczyznowego rozwoju. Po trzecie, aby ten rozwój osiągnąć istotne jest rozpatrywanie problematyki gospodarowania kapitałem ludzkim z poziomu: jednostki (działania na rzecz samorozwoju i inwestowanie w kapitał ludzki np. pracowników); przedsiębiorstwa (umiejętne zarządzanie różnorodnością jako nieodłączny element strategii przedsiębiorstwa); gospodarki (rozwój i wzrost gospodarczy dzięki dążeniu do budowania konkurencyjnej gospodarki opartej na wiedzy).

\section{BIBLIOGRAFIA}

Andrejczuk M., Karta różnorodności. Korzyści z zarządzania różnorodnością. Karta różnorodności w Polsce, Forum Odpowiedzialnego Biznesu, Warszawa 2012.

Golinowska S. (red.), W trosce o pracę. Raport o rozwoju społecznym, Wydawnictwo Programu Narodów Zjednoczonych ds. Rozwoju, Warszawa 2004.

GUS, Kobiety i mężczyźni na polskim rynku pracy 2012, Zakład Wydawnictw Statystycznych, Warszawa 2012.

GUS, Kobiety i mężczyźni na polskim rynku pracy 2013, Zakład Wydawnictw Statystycznych, Warszawa 2014.

GUS, Kobiety i mężczyźni na rynku pracy, Zakład Wydawnictw Statystycznych, Warszawa 2004.

GUS, Monitoring rynku pracy. Kwartalna informacja o aktywności ekonomicznej ludności IV kwartał 2013, Zakład Wydawnictw Statystycznych, Warszawa 2013.

Hurek J., Maj M., Równość płci a innowacyjność - stan obecny i rekomendacje na przyszłość, Polska Agencja Rozwoju Przedsiębiorczości, Warszawa 2012.

Jarmołowicz W., Kalinowska B., Praca i płaca kobiet na polskim i unijnym rynku pracy, [w:] W. Jarmołowicz (red.), Przemiany na współczesnym rynku pracy, Wydawnictwo Forum Naukowe, Poznań 2010.

Kalinowska-Nawrotek B., Dyskryminacja kobiet na polskim rynku pracy, Wydawnictwo Akademii Ekonomicznej w Poznaniu, Poznań 2005.

Klugman J. (red.), Human Development Report 2010. The Real Wealth of Nations: Pathways to Human Development, Wydawnictwo Programu Narodów Zjednoczonych ds. Rozwoju, Nowy Jork 2010.

Knochenmuss K. (red), Mentoring dla kobiet. Szeroka droga do kariery. Projekt dla województwa lubuskiego, Wydawnictwo Sonar, Słubice 2010.

Kowalak T., Kobieta we współczesnym świecie, Wydawnictwo Wyższej Szkoły Ekonomicznej w Białymstoku, Białystok 2006.

Kryńska E., Kwiatkowski E., Podstawy wiedzy o rynku pracy, Łódź 2013.

Lisowska E. (red.), Gender Index. Monitorowanie równości kobiet i mężczyzn w miejscu pracy, Wydawnictwo Programu Narodów Zjednoczonych ds. Rozwoju, Warszawa 2007. 
Lisowska E., Sznajder A., Zarządzanie różnorodnością w miejscu pracy. Raport z I Edycji Barometru Różnorodności, Wydawnictwo Konfederacji Lewiatan, Warszawa 2013.

Mandal E. (red.), W kręgu gender, Wydawnictwo Uniwersytetu Śląskiego, Katowice 2007.

Reszke I., Nierówności płci w teoriach. Teoretyczne wyjaśnienie płci w sferze zawodowej, Polska Akademia Nauk, Instytut Filozofii i Socjologii, Warszawa 1991.

Roszkowska S., Kapitał ludzki a wzrost gospodarczy w Polsce, Łódź 2013.

Sadowska-Snarska C. (red.), Równowaga. Praca - życie - rodzina, Wydawnictwo Wyższej Szkoły Ekonomicznej w Białymstoku, Białystok 2008.

Wronowska G., Kapitał ludzki - ujęcie teoretyczne, Kraków 2012.

\section{Źródła internetowe}

Branka M., Rawłuszko M., Siekiera A., Zasada równości szans kobiet i mężczyzn w projektach Programu Operacyjnego Kapitał Ludzki, Wydawnictwo Ministerstwa Rozwoju Regionalnego, Warszawa 2009, www.efs.gov.pl/Wiadomosci/Documents/zasadarownociszans.pdf

Malik K. (red.), Human Development Report 2013. The Rise of the South: Human Progress in a Diverse World, Wydawnictwo Programu Narodów Zjednoczonych ds. Rozwoju, Nowy Jork 2013, http://hdr.undp.org/en/media/HDR_2013_EN_complete.pdf

Komisja Europejska, 2015, Jak zwiększyć liczbę kobiet na najwyższych stanowiskach?, http:// ec.europa.eu/news/justice/120305_pl.htm

UNDP, Gender Inequality Index: Indices and Data, Nowy Jork 2013, www:hdr.undp.org/en/ statistics/gii 